\title{
SOCIAL PART-TIME EMPLOYMENT: SOVIET THEATER OF THE ABSURD
}

\author{
Elena V. Bulyulina \\ Volgograd State University, Volgograd, Russian Federation
}

\begin{abstract}
Introduction. The article is devoted to the Soviet propaganda campaign of 1931-1934, which was called "sotssovmestitelstvo" (social part-time employment). To date, there are no studies on this issue. Methods and materials. The author uses the following methods: historical-genetic, archival-heuristic, source studies, classification, historical description and actualization. The sources for the research were archival documents, periodical press materials, normative legal acts and propaganda works of the first half of the 1930s. Analysis. Social part-time employment meant that workers after completing a shift at the enterprise would have to voluntarily and free of charge perform certain functions in public institutions. The theoretical basis of the campaign was the idea of Lenin about the possibility of the permanent and direct participation of the proletariat in the management of the state. The ideologists of the campaign tried to create the illusion of mass participation of workers "from the machine". For this purpose directors of plants were obliged to send part-time employees to state institutions, and heads of institutions - to create working conditions for them. The authorities declared the thesis on the advantage of the working class over the intelligentsia and its high moral qualities, which it a priori has due to its social origin. It was assumed that these qualities will allow workers to identify shortcomings in the work of state institutions and make proposals for the improvement of the state apparatus. The author of the publication shows how the campaign began, passed and ended, what its real results were. Results. According to the author, the following circumstances were the reason for the campaign: the economic situation forced the authorities to prohibit mass mobilization of workers from production to participate in various campaigns of party-Soviet bodies, but at the same time partySoviet ideologists were not going to abandon the thesis of the participation of workers in public administration. The campaign could not collapse completely and was forgotten for many years.

Key words: workers, social part-time employment, political propaganda campaigns, public administration, 1931-1934.

Citation. Bulyulina E.V. Social Part-Time Employment: Soviet Theater of the Absurd. Vestnik Volgogradskogo gosudarstvennogo universiteta. Seriya 4. Istoriya. Regionovedenie. Mezhdunarodnye otnosheniya [Science Journal of Volgograd State University. History. Area Studies. International Relations], 2020, vol. 25, no. 3, pp. 21-30. (in Russian). DOI: https://doi.org/10.15688/jvolsu4.2020.3.2
\end{abstract}

УДК 93/94:331

Дата поступления статьи: 23.12.2019

ББК 63.3 Дата принятия статьи: 17.03.2020

\section{СОЦСОВМЕСТИТЕЛЬСТВО: СОВЕТСКИЙ ТЕАТР АБСУРДА}

\author{
Елена Владимировна Булюлина \\ Волгоградский государственный университет, г. Волгоград, Российская Федерация
}

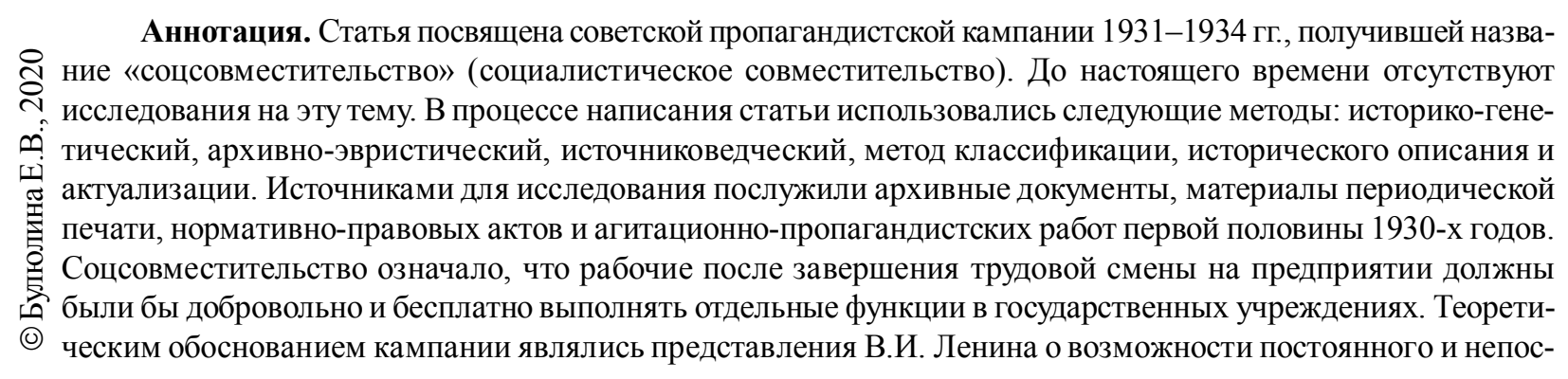




\section{СССР: ПРОБЛЕМЫ СОВЕТСКОЙ МОДЕРНИЗАЦИИ}

редственного участия пролетариата в управлении государством. Идеологи кампании пытались создать иллюзию массового участия в ней рабочих «от станка». Для этого директоров заводов обязывали направлять рабочих-соцсовместителей в государственные учреждения, а руководителей учреждений - создавать им условия работы. Власть декларировала тезис о преимуществе рабочего класса над интеллигенцией и его высоких морально-нравственных качествах, которые он априори имеет в силу своего социального происхождения. Предполагалось, что эти качества позволят рабочим-соцсовместителям выявлять недостатки в работе государственных учреждений и вносить предложения по усовершенствованию государственного аппарата. Автор публикации показал, как начиналась, проходила и закончилась кампания, каковы были ее реальные итоги. По мнению автора, причиной проведения кампании были следующие обстоятельства: экономическая ситуация вынуждала власть запретить массовые мобилизации рабочих с производства для участия в различных кампаниях партийно-советских органов, но в то же время партийно-советские идеологи не собирались отказываться от тезиса об участии рабочих в государственном управлении. Кампания не могла не закончиться полным провалом и на долгие годы была забыта.

Ключевые слова: рабочие, соцсовместительство, политические пропагандистские кампании, государственное управление, 1931-1934 годы.

Цитирование. Булюлина Е. В. Соцсовместительство: советский театр абсурда // Вестник Волгоградского государственного университета. Серия 4, История. Регионоведение. Международные отношения. - 2020. T. 25, № 3. - C. 21-30. - DOI: https://doi.org/10.15688/jvolsu4.2020.3.2

Введение. Термин «соцсовместительство» (социалистическое совместительство) появился в официальных партийно-советских документах и на страницах советской печати в 1930 г., а в конце 1934 г. уже канул в Лету. С 1935 г. полностью прекратилось его упоминание где-либо. Исследованию этого феномена посвящена данная статья.

Методы и материалы. До настоящего времени отсутствуют работы, в которых этому явлению было бы уделено пристальное внимание. В течение 1932-1934 гг. было издано несколько брошюр агитационно-пропагандистского характера, посвященных шефству предприятий над госаппаратом и соцсовместительству [2; 6; 9]. Авторами этих работ были работники аппарата Наркомата рабоче-крестьянской инспекции (далее НК РКИ СССР), руководящих советских и профсоюзных органов. Не являясь историческими исследованиями, эти работы тем не менее имеют большую историческую ценность, так как отражают текущую политическую ситуацию в стране и официальную позицию по вопросу соцсовместительства. В связи с тем, что кампания по развитию соцсовместительства провалилась, о ней забыли на долгие годы, и лишь в позднесоветских работах, так или иначе касающихся вопросов рабочего шефства над госаппаратом, имеются краткие упоминания об этом явлении $[1 ; 7]$. Обходят стороной этот вопрос и современные авторы.
Источниками для написания данной статьи послужили документы центральных и местных органов НК РКИ СССР, нормативно-правовые акты органов власти и управления, материалы ведомственной и периодической печати.

В процессе написания статьи использовались следующие методы: историко-генетический, архивно-эвристический, источниковедческий, метод классификации, исторического описания и актуализации.

Анализ. Определение соцсовместительству было дано в постановлении президиума Центральной контрольной комиссии (ЦКК) ВКП(б) и коллегии НК РКИ СССР от 19 августа 1931 г.: «Социалистическое совместительство заключается в том, что рабочие, оставаясь на производстве, бесплатно выполняют отдельные функции управления в соваппарате...» [21, с. 32]. Теоретическим обоснованием для творцов этого термина явилась фраза В.И. Ленина из работы 1918 г. «Очередные задачи Советской власти»: «Целью нашей является бесплатное выполнение государственных обязанностей каждым трудящимся, по отбытии 8-часового “урока” производительной работы» [12, с. 204].

Авторы уже упоминавшихся агитационно-пропагандистских работ 1932-1934 гг. стремились представить, что соцсовместительство как форма участия рабочих от станка в государственном управлении возникло по инициативе самих рабочих: «Нелегко установить, какой из заводов впервые установил институт 
соцсовместителей, да в конце концов, это не так важно. Соцсовместительство стало почти одновременно делом многих заводов» [9, c. 28]. Однако это не так. Установить конкретного автора концепции соцсовместительства действительно не представляется возможным, но бесспорно, что эта идея принадлежала ЦКК-НК РКИ СССР.

НК РКИ СССР, преобразованный в 1920 г. из Наркомата государственного контроля, выполнял функции государственного контроля над всеми органами управления, хозяйственными и общественными организациями, на него возлагались также борьба с бюрократизмом в советских учреждениях, наблюдение за проведением в жизнь декретов и постановлений советской власти, усовершенствование управления [19]. В 1923 г. НК РКИ СССР был объединен с ЦКК ВКП(б) в единый орган партийногосударственного контроля. ЦКК-РКИ СССР должна была сосредоточить свое внимание в первую очередь на улучшении работы госаппарата, его рационализации, борьбе с бюрократизмом. В 1928 - начале 1930-х гг. органам РКИ было поручено особое задание - проведение проверки и «чистки» личного состава государственных учреждений в соответствии с инструкцией НК РКИ СССР. В ней указывалось, что РКИ «организует чистку советского аппарата от элементов разложившихся, извращающих советские законы, сращивающихся с кулаком и нэпманом, мешающих бороться с волокитой и ее прикрывающих, высокомерно, по-чиновничьи, по-бюрократически относящихся к насущным нуждам трудящихся, от растратчиков, взяточников, саботажников, вредителей» [5, с. 122].

Вопрос о чистках госаппарата подробно изучен отечественными историками [8; 11 ; 20]. Он не является предметом нашего исследования. Отметим лишь, что разворачивающаяся под флагом борьбы с бюрократизмом чистка госаппарата превратилась в откровенно циничное преследование людей по политическим и социальным мотивам. Для нашей работы важно следующее обстоятельство: руководство чисткой возлагалось на специальную комиссию по чистке советского аппарата при НК РКИ СССР и ее местные органы при краевых и окружных РКИ. В состав комиссии, помимо сотрудников РКИ, входили предста- вители прокуратуры, отдела труда, профсоюза и два «рабочих от станка». С развертыванием чисток привлечение рабочих к их проведению стало более широким и разнообразным: из рабочих формировались отряды «летучих ревизий», общественные инспектуры, совещания рабочих заседателей и прочее.

По справедливому замечанию Т.П. Коржихиной, для государственной идеологии СССР была характерна «апологетика нравственного преимущества "простого человека", который «университетов не кончал», но все видит и понимает лучше любого грамотеяинтеллигента» $[10$, с. 321]. Рабочие изначально наделялись такими качествами, как высокая нравственность, порядочность, честность, которые вместе с классовым самосознанием и пролетарской принципиальностью помогут вскрыть и исправить все недостатки государственного управления.

Чистки вызвали к жизни такие массовые явления, как «шефство предприятий над госаппаратом» и «выдвиженчество», то есть направление на работу на административные и хозяйственные должности в госучреждения рабочих от станка. Выступая на XVI съезде ВКП(б), проходившем с 26 июня по 13 июля 1930 г., с отчетом ЦКК, Г.К. Орджоникидзе говорил об этом так: «В процессе чистки приняло довольно широкие размеры шефство заводов над аппаратом. Это не шефство в традиционном смысле, а действительное осуществление контроля рабочих масс над госаппаратом. Заводы посылают своих рабочих, чтобы чистить свое подшефное учреждение. Эти рабочие знакомятся как со структурой аппарата, так и людским составом... В процессе самой чистки уже выдвигаются те рабочие, которые потом остаются в аппарате. Этот рабочий уже не так боязливо подходит к аппаратному чиновнику, ибо он его вчера чистил, он его вычищал, и теперь, приходя в аппарат работать, он чувствует себя как хозяин» [23, с. 316-317].

И шефство, и выдвиженчество не представляли собой инициативу рабочих, как это декларировалось властью, а директировались партийно-советским руководством. Еще до проведения XVI съезда, 15 марта 1930 г., было опубликовано постановление ЦК и ЦКК ВКП(б) «О выдвижении рабочих в советский 


\section{СССР: ПРОБЛЕМЫ СОВЕТСКОЙ МОДЕРНИЗАЦИИ}

аппарат и массовом рабочем контроле снизу над советским аппаратом (шефстве заводов)», в котором четко определялось: «Ответственность за систематическое вовлечение рабочих в госаппарат, руководство работой выдвиженцев, создание для них нормальных условий работы и повышение их квалификации возлагается на руководителей учреждений» [21, с. 9].

Выполняя директивы, директор и партийно-профсоюзный актив завода должны были провести общее собрание коллектива предприятия, на котором объявлялось о шефстве завода над конкретным госучреждением или группой учреждений, заключался шефский договор и выбирались члены рабочих шефских бригад («шефбригад»). Зачастую этим дело и ограничивалось.

Как и при проведении любой другой кампании, власти необходимо было создать иллюзию массового участия трудящихся в работе по усовершенствованию госаппарата и устранению его недостатков. Но каков же был реальный вклад рабочих-участников этого процесса? Какие недостатки управления могли выявить люди, не имевшие никакого представления об особенностях управленческого труда, структуры и функций обследуемых ими учреждений? Характерна обида одного такого рабочего, которому в проверяемом им учреждении предоставили документы для ознакомления с работой организации: «Человек пришел оказать помощь госаппарату, а ему дают кипу бумаг и больше ничего» [6, с. 38]. Как правило, предложения членов шефбригад сводились к удалению «лишних» штатных единиц, состоявших в основном из «чужаков» и «разложившихся». Надо ли говорить, что к этим категориям можно было отнести кого угодно. Рабочие ленинградского текстильного завода им. К. Маркса, шефствовавшие над финансовыми учреждениями города, пошли еще дальше. Ознакомившись с работой Госстраха, они направили письмо в ЦК ВКП(б) и СНК СССР о том, что «можно чем скорее, тем лучше поставить большой крест на весь Госстрах. Можно упразднить Госстрах не только без всякого вреда для народного хозяйства, но и с прямой пользой» [23, с. 317].

Власть усиленно подпитывала в рабочих чувство исключительности, классового пре- восходства. Рабочие, участвовавшие в чистках госучреждений, становились инициаторами увольнения значительного количества специалистов по причине их «социально-чуждого» происхождения. Занимая места уволенных, выдвиженцы становились преданной опорой власти. Решающими для их карьерного роста становились не образование и квалификация, а членство в партии, социальное происхождение, следование «генеральной линии», активная борьба с врагами советской власти и т. п.

Чистки учреждений продолжались довольно продолжительное время и привлекали значительное количество рабочих, которые хоть и отрывались «от станка», но продолжали получать зарплату на предприятии. Кроме чисток, рабочий актив принимал участие в других кампаниях, что в конце концов не могло не отразиться на выполнении производственных планов. В сторону чрезмерно увлекшихся общественной работой вскоре последовал начальственный окрик: 25 марта 1931 г. было принято постановление ЦК ВКП(б) и СНК СССР «О полном прекращении мобилизации рабочих от станка на нужды текущих кампаний местными партийными, советскими и другими организациями» [16]. В постановлении запрещались любые мобилизации рабочих с производства и административно-технического персонала в промышленности и на транспорте на всякого рода кампании, проводимые партийными, советскими, комсомольскими, профсоюзными и другими органами, в том числе запрещалось отвлекать рабочих и административно-технический персонал в различного рода обследовательские бригады. Учеба и общественная работа должна была проводиться только в нерабочее время. Ответственность за исполнение этой директивы возлагалась на директоров заводов.

Но как же было совместить новые указания и пресловутое участие рабочих в управлении государством? Тем более что власть и не думала отказываться от этого. В том же 1931 г. была в очередной раз переиздана работа И.В. Сталина «Вопросы ленинизма», в которой он, в частности, писал: «Исправить госаппарат, переделать его по-настоящему, изгнать из него элементы бюрократизма и разложения, сделать его близким и родным для широких масс, - все это невозможно без 
постоянной и активной помощи самих масс госаппарату. Но активная и непрерывная помощь масс, в свою очередь, невозможна без вовлечения лучших элементов рабочих и крестьян в органы управления» [22, с. 182].

Вновь вспомнили о фразе Ленина о «бесплатном выполнении государственных обязанностей каждым трудящимся» после 8-часового рабочего дня на производстве. Годом ранее, на XVI съезде ВКП(б), этот тезис широко обсуждался в прениях по докладу Г.К. Орджоникидзе. Выступавшие недоумевали, «как можно так организовать свою работу, чтобы в нее включился рабочий, который днем работает на производстве, а свое свободное время отдает работе в соваппарате?» [23, с. 347]. Делегаты рассказывали, как они пытались наладить работу «шефов»: поручали им проверять переписку, организовывали дежурства по наблюдению за работой аппарата, проводили с ними занятия по изучению отраслевого законодательства и др. Представители учреждений жаловались, что, испробовав различные формы привлечения рабочих к управлению, не могут «органически связать пришедших товарищей с работой, заинтересовать их в ней, сделать так, чтобы она органически вытекала из плана работы ведомства, а не была придумана специально», что они «тяжко бьются над разрешением этого вопроса» $[23$, с. 347,375$]$. Все единодушно сошлись во мнении, что ЦКК-РКИ должна помочь в разрешении этой задачи. Однако внятного ответа на поставленный вопрос делегаты съезда так и не получили. Но сама концепция у руководителей ЦКК-РКИ уже оформилась: так как в процессе чистки госаппарата тысячи рабочих ознакомились с работой отдельных его звеньев, вполне возможно поручить рабочим-членам шефбригад выполнение некоторых управленческих функций в подшефном учреждении после основной работы на производстве, в порядке общественной нагрузки.

Сам же термин «соцсовместительство» появился в апреле 1931 г. на страницах целого ряда органов пролетарской печати, таких как газеты «Ленинградская правда», «Смена», «Красная газета» и др. 22 апреля 1931 г. президиум Леноблисполкома и Ленсовета постановил: «Ввести в советских, хозяйственных, кооперативных и культурных учреждениях и организациях институт соцсовместителей для выполнения ими в нерабочее время обязанностей инспекторов, контролеров и исполнителей ответственных поручений» [9, с. 28].

Почин ленинградских властей был растиражирован и рекомендован другим регионам, но ни в самом Ленинграде, ни где-либо еще не было ясного понимания, как же конкретно организовать работу соцсовместителей. В связи с этим было издано постановление президиума ЦКК ВКП(б) и коллегии НК РКИ СССР от 19 августа 1931 года. В нем констатировалось, что соцсовместительство, возникшее и развивающееся на базе шефской работы, является новой формой непосредственного участия рабочих в управлении государством и создает новые возможности для привлечения рабочих масс к борьбе с бюрократизмом. Отмечалось, что в тех учреждениях, где соцсовместителям была оказана помощь со стороны администрации, эта форма дала положительные результаты: «...Рабочие-соцсовместители, выполняя в соваппарате работу заместителей, заведующих отделами, секторами и управлениями, в качестве инспекторов, инструкторов и т. д., справляются с порученной им частью работы и внедряют методы соцсоревнования и ударничества в работу соваппарата» [21, с. 32]. В постановлении приводилось 3 положительных примера: в Наркомате юстиции работают 8 соцсовместителей; в Московской области 234 соцсовместителя выполняют функции резервных судей; «несколько рабочих завода им. Лепсе, состоя совместителями в секторе контроля Наркомпроca, успешно развернули работу по организации проверки исполнения» [21, с. 33]. На этом положительные примеры исчерпывались.

Далее речь шла о том, что в целом работа по соцсовместительству по-настоящему не поставлена, ведется несистемно. Соцсовместителей назначают «аппаратным порядком», не оказывают им помощь, в результате, приходя в учреждения, они не получают конкретного задания или используются на случайной, технической или канцелярской работе. В заключение всем «партийным, комсомольским, профсоюзным, советским и кооперативным организациям» предлагалось обеспечить помощь соцсовместителям, создать необхо- 


\section{СССР: ПРОБЛЕМЫ СОВЕТСКОЙ МОДЕРНИЗАЦИИ}

димые условия для их работы, следить за их правильным использованием [21, с. 34].

На деле же получалось следующее. Руководителей предприятий обязывали организовать шефство над учреждениями и выделить определенное количество соцсовместителей, которые бы добровольно и бесплатно отправились в подшефную организацию «во вторую смену», чтобы искоренять недостатки в аппарате управления. При этом озабоченным выполнением промфинплана директорам заводов было, разумеется, не до шефской работы. Еще Орджоникидзе на XVI съезде отмечал: «Налицо некоторое ослабление внимания со стороны шефов к подшефным учреждениям. Когда чистили, было как-то весело, а когда надо следить за повседневной работой, уже не то... Мы имеем громадное количество шефствующих заводов и рабочих, участвующих в этом шефстве. Но мало сказать о количестве шефов, необходимо, чтобы шефы были активны» [23, с. 317]. Администрацией предприятий шефство воспринималось, как очередная кампания, о которой надо побыстрее отчитаться и забыть. Периодическая печать того времени пестрит примерами: «Завком завода “Красный Якорь” не знает даже, над каким учреждением шефствует завод. Одни утверждают, что над скотобойней, другие - что над крайпроизводсоюзом»; на Астраханском заводе им. Ленина-шефе крайпотребсоюза шефские бригады распались изза «оппортунистически-бюрократического отношения руководителей завода и крайпо» и т. п. $[14$, с. 3$]$.

Отмечались факты недооценки политического значения соцсовместительства не только в провинции, но и в Москве и Ленинграде. Предприятия «выбирают в соцсовместители, кого придется»: в Ленинграде на заводе им. Энгельса выбрали соцсовместителей в возрасте 62, 68 и 72 лет, на заводе «Большевик» - шестнадцатилетнего, на заводе «Красный Богатырь» - рабочих с трехмесячным стажем. Никакого руководства соцсовместителями со стороны предприятий и организаций нет, а работу в этом направлении начинают только после появления критических публикаций [9, с. 57-59].

Имеется много свидетельств самих соцсовместителей, как они чувствовали себя, приходя в учреждение. Вот что рассказывал рабочий Карпов (по обычаю тех лет ни имяотчество, ни хотя бы инициалы в официальных документах и печати, как правило, не указывались): «Соцсовместители, приходя в аппарат, часто не знали, куда деться, с чего начать работу. С этим пришлось столкнуться и мне. В цеху мне сказали: “Тебе все приготовят, тебе разъяснят, что ты должен делать". Я думал, что приду и все это встречу. Оказывается, ничего подобного. Начальник собирался куда-то выехать. Он вызвал одного из специалистов, чтобы тот показал мне аппарат. Начал он мне показывать аппарат: - Вот тут то-то и то-то, здесь снабжение, здесь распределение и т. д. - А пока, - он говорит, мне некогда, я тебя посажу за стол и дам коечто, чтоб ты ознакомился. Меня посадили в уголок и принесли с пуд папок, покрытых пылью. Я остался один. Посматривали на меня, хихикали, как, мол, он работать будет. Я повернул одну папку, другую, третью - ничего не понимаю. Посидел еще немного, вижу дело неловкое, пошел по учреждению посмотреть. Нашел партячейку, в ней секретаря, он помог мне начать работу...» [6, с. 37].

Рабочий Чернышев, посланный соцсовместителем в районо: «Работу дают отрывками, посидишь немного в аппарате, а тебе говорят: - Приди лучше завтра. Ходишь, ходишь, а результатов нет, решил бросить» $[2$, с. 28$]$.

Можно только посочувствовать людям, поставленным в такую нелепую ситуацию. Собственное предприятие, выдвинув их в соцсовместители, тут же о них забыло и предоставило самим себе, а в учреждении они лишние. Но каково при этом было руководителям учреждений! Их постоянно критикуют, что они не помогают соцсовместителям, не обеспечивают им систематический инструктаж, не выделяют ответственных за их работу, не приглашают на свои совещания. Попытки отказаться от совместителей, мешающих работать, чреваты обвинениями в оппортунизме, бюрократизме и т. п. Если рабочего, например, электромонтера, пытаются занять работой по специальности, следует обвинение в том, что квалифицированного производственника, присланного для несения функций госуправления, используют как бесплатную рабо- 
чую силу. Многие руководители учреждений делают соответствующие выводы: оформляют соцсовместителей приказом, прикрепляют к ним ответственного - заведующего отделом или работника кадровой службы, ведут учет их работы, пишут для них памятки и инструкции. Так, Московский областной суд в 1931 г. выпустил практическое пособие «В помощь народному заседателю и судье-выдвиженцу» [3]. В предисловии к нему было сказано: «Многие товарищи народные судьи, в особенности из выдвиженцев, и народные заседатели часто заявляют о трудности руководствоваться судебными законами и ведомственными постановлениями по причине их громоздкости, а отчасти неясности их изложения. Тем более эти трудности ими испытываются в начальной стадии их работы, когда они не знакомы еще с судебной политикой и практикой». В пособии помещались с пояснениями статьи Уголовного и Гражданского кодексов, чаще всего встречавшиеся в судебной практике тех лет. Можно представить судопроизводство с участием судей, «не знакомых еще» с судебной практикой. Между тем соцсовместители работали и в аппарате прокуратуры в качестве помощников прокуроров, «разбирали дела» и выступали в качестве государственных обвинителей в суде [13, л. 64].

При этом не все соцсовместители одиноко и неприкаянно бродят по учреждению. Некоторые из них весьма активны и напористы. Ощущающие себя «гегемонами», пренебрежительно относящиеся к образованным интеллигентам, развращенные участием в чистках и поощряемые властью эти рабочиешефы действительно пытаются реорганизовать госаппарат по своему разумению. Вспомним предложение упразднить Госстрах. Или еще пример: изучив работу Публичной библиотеки, рабочие-шефы ленинградского завода «Знамя труда» № 1 поставили вопрос «перед соответствующими инстанциями» о смене всего руководства библиотеки [9, с. 52-53].

В течение 1932-1934 гг. вопрос о рабочем шефстве над госаппаратом и соцсовместительстве неоднократно рассматривается в центральных и местных органах ЦКК-РКИ, исполкомах Советов, на партийных конференциях. Документы фиксируют одно и то же: «С шефством предприятий над госаппаратом дело обстоит плохо» [4, л. 57]; «очень плохо с работой соцсовместителей» [13, л. 16]; «в вопросе соцсовместительства перелома не наступило» [17, л. 238]; «большинство заводских организаций подошли формально к выделению соцсовместителей и не осуществляли повседневного контроля и помощи в их работе... в большинстве учреждений не были созданы благоприятные условия для их работы, в результате большинство соцсовместителей фактически не работало» $[15$, л. 20]. Руководителям предприятий и учреждений грозят строгими санкциями, но ситуация не меняется.

10 марта 1934 г. в Москве открылся «I Всесоюзный съезд рабочих шефбригад и соцсовместителей, работающих в госучреждениях, объединяемых профсоюзом работников госучреждений $\mathrm{CCCP»} \mathrm{[18].} \mathrm{Во} \mathrm{вступи-}$ тельной речи Н.М. Шверник, в то время первый секретарь ВЦСПС, сказал, что «огромная масса рабочих и работниц после 7-часового рабочего дня приходит в учреждения и помогает рационализировать работу, борется с бюрократизмом, переносит опыт организации труда на производстве в государственные учреждения» $[18$, с. 7$]$. Он привел следующую цифру: свыше 14 тыс. рабочих-участников шефбригад и соцсовместителей в центральных учреждениях, объединенных профсоюзом работников госучреждений. Е.М. Ярославский, член Президиума КК-РКИ, и М.М. Каганович, секретарь ЦК профсоюза работников госучреждений, указали другие цифры: около 10 тыс. участников шефбригад и столько же соцсовместителей $[18$, с. 25]. Правда, участники обсуждения докладов в прениях отмечали, что не все соцсовместители регулярно работают, среди них большая текучка и т. п. Съезд констатировал, что не только предприятия и организации не выполнили указаний ЦКК-РКИ и недооценили политического значения соцсовместительства, но и профсоюзы «не сделали всего того, что нужно сделать для развертывания массового контроля рабочих над госаппаратом и работы в нем соцсовместителей» $[18$, с. 8]. Таким образом, с 1931 г. не продвинулись ни на шаг. Кампания явно начала выдыхаться. Значительно уменьшилось количество публикаций в периодической печати на тему рабочего шефства и соцсовместительства (их пик пришелся на 1932 г.). 


\section{СССР: ПРОБЛЕМЫ СОВЕТСКОЙ МОДЕРНИЗАЦИИ}

В опубликованных в 1934 г. агитационно-пропагандистских работах авторы пытались подвести некоторые итоги работы по соцсовместительству. Об уровне этих работ можно судить по небольшому отрывку, в котором автор одной из брошюр определяет перспективы соцсовместительства: «В Ленинграде рабочий-соцсовместитель металлургического завода им. Сталина замещает директора бывшего Мариинского театра, в ряде медицинских институтов в качестве заместителей директоров мы так же находим рабочих от станка... Разумеется, это только начало утра того длительного исторического дня, который приведет, наконец, к полному устранению противоположности между умственным и физическим трудом. Пусть только начало, но о каком чудесном дне, о каком пышном расцвете тех побегов, которые пышно вырастают с каждым днем в пролетарском государстве, говорит это начало» $[9$, с. 99].

Однако после 1934 г. о соцсовместительстве уже не упоминали.

Результаты. Таким образом, вся история соцсовместительства представляет собой историю одной из многочисленных советских идеолого-пропагандистских кампаний. Концепция соцсовместительства была основана на утопическом представлении В.И. Ленина о возможности непосредственного и постоянного участия пролетариата в управлении государством. Она была сформулирована в 1931 г. с целью устранить противоречия между запрещением массовых мобилизаций рабочих с производства для участия в различных кампаниях партийносоветских органов и тезисом об участии этих же рабочих в государственном управлении. В течение последующих трех лет власти не оставляли попыток реализовать эту концепцию и создать иллюзию массового участия трудящихся в соцсовместительстве. Эти попытки потерпели крах, а соцсовместительство предано забвению.

\section{СПИСОК ЛИТЕРАТУРЫ}

1. Андреев, В. П. Руководство Коммунистической партии городскими Советами РСФСР (19261937 гг.) / В. П. Андреев. - Томск : Изд-во Томск. унта, 1990. -227 c.
2. Брук, А. Шефство и соцсовместительство / А. Брук. - М. : Власть Советов, 1932.-36 с.

3. В помощь народному заседателю и судьевыдвиженцу. - М. : Изд-во Мособлисполкома, 1931. $-108 \mathrm{c}$.

4. Докладная записка Сталинградского городского Совета о ходе шефства города над деревней и предприятий над госаппаратом от 15 августа 1931 г. // Государственный архив Волгоградской области (далее-ГАВО). -Ф. Р-71.-Оп. 1. -Д. 496. - Л. 57-58.

5. Известия Нижневолжского краевого исполнительного комитета. - 1929. - № 15-16.

6. Каганович, М. Шефство и соцсовместительство в госаппарате / М. Каганович, Г. Зеленко. - М. : Профиздат, 1934. $-87 \mathrm{c}$.

7. Калинин, А. Ф. Деятельность Коммунистической партии по совершенствованию работы Советов в годы первой и второй пятилеток (на материалах Ленинградской партийной организации) : дис. ... д-ра ист. наук / Калинин Анатолий Фролович. - Л., 1984. -373 с.

8. Киселева, Е. Л. Чистка госаппарата 1929 1932 гг.: основные комплексы источников, их анализ и значение : дис. ... канд. ист. наук / Киселева Екатерина Львовна. - М., 2014. - 40 c.

9. Карева, М. П. Шефство и соцсовместительство / М. П. Карева. - Л. : Изд-во облиисполкома и Ленсовета, 1932. - $123 \mathrm{c}$.

10. Коржихина, Т. П. Извольте быть благонадежны! / Т. П. Коржихина. - М. : РГГУ, 1997.-372 с.

11. Котов, А. С. Социальный состав советской интеллигенции в 1920-е гг. (на примере Череповецкой губернии и Череповецкого округа) / А. С. Котов // Вестник Тамбовского гос. ун-та. Серия: Гуманитарные науки. История и политология. $-2013 .-$ Вып. 6(122). - С. 176-180.

12. Ленин, В. И. Полное собрание сочинений : в 55 т. / В. И. Ленин ; Ин-т марксизма-ленинизма при ЦК КПСС. - 5-е изд. - М. : Политиздат, 1974. T. $36 .-741 \mathrm{c}$.

13. Отчет о работе городской КК-РКИ за 1931 г. // Центр документации новейшей истории Волгоградской области (далее - ЦДНИВО). - Ф. 24. Оп. 1. - Д. 22. - Л. 16-64.

14. Поволжская правда. $-1931 .-30$ апр. -4 л.

15. Постановление коллегии Сталинградской городской РКИ от 17 февраля 1932 г. № 80 // ЦДНИВО. Ф. 24. - Оп.1.- Д. 88а. - Л. 20-21.

16. Постановление ЦК ВКП (б) и СНК СССР от 25 марта 1931 г. «О полном прекращении мобилизации рабочих от станка на нужды текущих кампаний местными партийными, советскими и другими организациями» // Библиотека нормативно-правовых актов СССР. - Электрон. текстовые дан. - Режим доступа: http://www.libussr.ru/doc_USSR/ USSR_3708.htm (дата обращения: 20.01.2020). 
17. Протокол объединенного заседания Президиума Сталинградской городской КК и коллегии РКИ от 13 декабря 1932 г. № 73 // ЦДНИВО. - Ф. 24. Оп. 1. - Д. 89. - Л. 238-240.

18. Рабочее шефство и соцсовместительство на высшую ступень : материалы I Всесоюзного съезда рабочих шефбригад и соцсовместителей, объединяемых профсоюзом работников госучреждений. - М. : Власть Советов, 1934. - 112 с.

19. Сборник узаконений и распоряжений советского рабоче-крестьянского правительства (СУ РСФСР). - 1920. - № 16. - Ст. 94.

20. Смирнова, Т. М. Чистки как часть советской повседневности 1920-1930-х гг. / Т. М. Смирнова // Вестник РУДН. Серия История России. - 2009. № 3. - С. 103-120.

21. Смотр массовой работы КК-РКИ. Сборник руководящих материалов по вопросам шефства над госаппаратом, соцсовместительства и совместной работы КК-РКИ и профсоюзов. - М. : Изд-во Мособлисполкома, 1933. - 48 с.

22. Сталин, И. В. Вопросы ленинизма/ И. В. Сталин. - Изд. 7, доп. - М. ; Л. : Госиздат, 1931.- 803 с.

23. XVI съезд ВКП(б) : стенограф. отчет. - М. ; Л. : Госиздат, 1930. -786 с.

\section{REFERENCES}

1. Andreev V.P. Rukovodstvo Kommunisticheskoy partii gorodskimi Sovetami RSFSR (1926-1937 gg.) [The Leadership of the Communist Party of Municipal Councils of the RSFSR (1926-1937)]. Tomsk, Izd-vo Tomskogo universiteta, 1990. $227 \mathrm{p}$.

2. Bruk A. Shefstvo i sotssovmestitelstvo [Patronage and Social Part-Time Employment]. Moscow, Vlast Sovetov Publ., 1932. 36 p.

3. V pomoshch narodnomu zasedatelyu $i$ sudevydvizhentsu [In Aid of the Peoples Assessor and Judge-Nominee]. Moscow, Izd-vo Mosoblispolkoma, 1931. 108 p.

4. Dokladnaya zapiska Stalingradskogo gorodskogo Soveta o khode shefstva goroda nad derevney i predpriyatiy nad gosapparatom ot 15 avgusta 1931 g. [Report of the Stalingrad City Council on the Patronage of the City Over the Village and Enterprises Over the State Apparatus of August 15, 1931]. Gosudarstvennyy arkhiv Volgogradskoy oblasti [State Archive of Volgograd Region], F. R-71, Op. 1, D. 496, L. 57-58.

5. Izvestiya Nizhnevolzhskogo kraevogo ispolnitelnogo komiteta, 1929, no. 15-16.

6. Kaganovich M., Zelenko G. Shefstvo $i$ sotssovmestitelstvo $v$ gosapparate [Patronage and Social Responsibility in the State Apparatus]. Moscow, Profizdat, $1934.87 \mathrm{p}$.
7. Kalinin A.F. Deyatelnost Kommunisticheskoy partii po sovershenstvovaniyu raboty Sovetov $v$ gody pervoy $i$ vtoroy pyatiletok (na materialakh Leningradskoy partiynoy organizatsii): dis. ... d-ra ist. nauk [Activity of the Communist Party on Improvement of the Work of the Soviets in the Years of the First and Second Five-Year Plans (On the Materials of the Leningrad Party Organization). Dr. hist. sci. diss.]. Leningrad, 1984. 373 p.

8. Kiseleva E.L. Chistka gosapparata 19291932 gg.: osnovnye kompleksy istochnikov, ikh analiz $i$ znachenie: dis. ... kand. ist. nauk [Cleaning of the State Apparatus 1929-1932: Main Complexes of Sources, Their Analysis and Significance. Cand. hist. sci. diss.]. Moscow, 2014. 40 p.

9. Kareva M.P. Shefstvo i sotssovmestitelstvo [Patronage and Social Part-Time Employment]. Leningrad, Izd-vo obliispolkoma i Lensoveta, 1932. $123 \mathrm{p}$.

10. Korzhikhina T.P. Izvolte byt blagonadezhny! [Please Be Trustworthy!]. Moscow, RGGU, 1997.372 p.

11. Kotov A.S. Sotsialnyy sostav sovetskoy intelligentsii v 1920-e gg. (na primere Cherepovetskoy gubernii i Cherepovetskogo okruga) [The Social Composition of the Soviet Intelligentsia in the 1920s (On the Example of Cherepovets Province and Cherepovets District)]. Vestnik Tambovskogo gos. unta. Seriya: Gumanitarnye nauki. Istoriya $i$ politologiya [Tambov University Review. Series: Humanities], 2013, iss. 6(122), pp. 176-180.

12. Lenin V.I. Polnoe sobranie sochineniy: $v 55 t$. [Complete Collection of Works in 55 Vols.]. Moscow, Politizdat, 1974, vol. 36. 741 p.

13. Otchet o rabote gorodskoy KK-RKI za $1931 \mathrm{~g}$. [Report on the Work of the City Control Commission and Workers and Peasants Inspection for 1931]. Tsentr dokumentatsii noveyshey istorii Volgogradskoy oblasti [Documentation Centre of Modern History of Volgograd Region], F. 24, Op. 1, D. 22, L. 16-64.

14. Povolzhskaya Pravda, April 30, 1931. 41.

15. Postanovlenie kollegii Stalingradskoy gorodskoy RKI ot 17 fevralya 1932 g. № 80 [Resolution of the Board of the Stalingrad City Workers and Peasants Inspection of February 17, 1932 no. 80]. TsDNIVO [Documentation Centre of Modern History of Volgograd Region], F. 24, Op. 1, D. 88a, L. 20-21.

16. Postanovlenie TsK VKP (b) i SNK SSSR ot 25 marta 1931 g. «O polnom prekrashchenii mobilizatsii rabochikh ot stanka na nuzhdy tekushchikh kampaniy mestnymi partiynymi, sovetskimi i drugimi organizatsiyami» [Resolution of the Central Committee of the All-Union Communist Party (Bolsheviks) and the Council of Peoples Commissars of the USSR of March 25, 1931 "On the Complete Cessation of Mobilization of Workers from the Machine for the Needs of Current Campaigns by Local Party, Soviet 


\section{СССР: ПРОБЛЕМЫ СОВЕТСКОЙ МОДЕРНИЗАЦИИ}

and Other Organizations»]. Biblioteka normativnopravovykh aktov SSSR [Library of Normative Legal Acts of the USSR]. URL: http://www.libussr.ru/doc USSR/USSR_3708.htm (accessed 20 January 2020).

17. Protokol obyedinennogo zasedaniya Prezidiuma Stalingradskoy gorodskoy KK i kollegii RKI ot 13 dekabrya 1932 g. № 73 [Minutes of the Joint Meeting of the Presidium of the Stalingrad City Control Commission and the Board of Workers and Peasants Inspection of December 13, 1932 no. 73]. TsDNIVO [Documentation Centre of Modern History of Volgograd Region], F. 24, Op. 1, D. 89, L. 238-240.

18. Rabochee shefstvo i sotssovmestitelstvo na vysshuyu stupen: materialy I Vsesoyuznogo syezda rabochikh shefbrigad $i$ sotssovmestiteley, obyedinyaemykh profsoyuzom rabotnikov gosuchrezhdeniy [Workers Patronage and Social PartTime Employment at the Highest Level: Proceedings of the I All-Union Congress of Groups of Workers and Social Part-Time Employees United by the Trade Union of Employees of State Institutions]. Moscow, Vlast Sovetov Publ., 1934. 112 p.

19. Sbornik uzakoneniy i rasporyazheniy sovetskogo raboche-krestyanskogo pravitelstva (SU
RSFSR) [Collection of Laws and Orders of the Soviet Workers and Peasants Government], 1920, no. 16, art. 94.

20. Smirnova T.M. Chistki kak chast sovetskoy povsednevnosti 1920-1930-kh gg. [Purges as Part of Soviet Everyday life in the 1920s and 1930s.]. Vestnik RUDN. Seriya Istoriya Rossii [RUDN Journal of Russian History], 2009, no. 3, pp. 103-120.

21. Smotr massovoy raboty KK-RKI. Sbornik rukovodyashchikh materialov po voprosam shefstva nad gosapparatom, sotssovmestitelstva i sovmestnoy raboty KK-RKI i profsoyuzov [Review of the Mass Work of the Control Commission and Workers and Peasants Inspection. Collection of Guidelines on Patronage over the State Apparatus, Social Part-Time Employment and Joint Work of the Control Commission and Workers and Peasants Inspection and Trade Unions]. Moscow, Izd-vo Mosoblispolkoma, 1933. 48 p.

22. Stalin I.V. Voprosy leninizma [Issues of Leninism]. Moscow, Leningrad, Gosizdat, 1931. 803 p.

23. XVI syezd VKP(b): stenograf. otchet [XVI Congress of the All-Union Communist Party (Bolsheviks): Verbatim Report], Moscow, Leningrad, Gosizdat, 1930. 786 p.

\section{Information About the Author}

Elena V. Bulyulina, Doctor of Sciences (History), Associate Professor, Leading Researcher, Department of Service and Tourism, Volgograd State University, Prosp. Universitetsky, 100, 400062 Volgograd, Russian Federation, ev_buljulina@volsu.ru, https://orcid.org/0000-0001-9253-3725

\section{Информация об авторе}

Елена Владимировна Булюлина, доктор исторических наук, доцент, ведущий научный сотрудник кафедры сервиса и туризма, Волгоградский государственный университет, просп. Университетский, 100, 400062 г. Волгоград, Российская Федерация, ev_buljulina@volsu.ru, https://orcid.org/0000-0001-9253-3725 